\title{
81 still here after 25 years!
}

Dot Griffiths

Feminist Review (FR) began life 25 years ago as a self-published journal. We met in houses and held an Annual Christmas Fair to raise money. After 25 years we are:-

- still a collective

- financially solvent

- shaped by the path of these 25 years

This path through the years has not always run smoothly, of course, and the speakers tonight will reflect different moments on this path and end with some thoughts for our future.

The story of FR is interesting and important in a number of ways. First, its survival and strength reflects the remarkable women who have contributed to it over the years, and on behalf of the current members of the Collective I would like to thank all the women who have contributed to FR over the years, and to thank so many of you for coming to join our celebration tonight. Second, FR has always been edited by a collective. Our commitment to this mode of working - while it has not always been easy - has remained unchanged. Third, we have now set up the Feminist Review Trust. From knitting and cooking to raise funds we now have financial stability and wanted to create a means to return this to the communities of scholarship and activism, which constitute contemporary feminisms. After a long debate about the word 'feminist' we have now been awarded charitable status for the Trust. The journal has made a long-term commitment to fund the Trust and we are very proud to have created it.

So, the first 25 years have been tumultuous, challenging, exciting and in many ways, a mirror of feminism(s). Here's to the next 25 years.

\section{author biography}

Dot Griffiths was one of the founder members of the FR Collective and has worked on it almost continuously for 25 years. She chaired the celebratory meeting.

doi: $10.1057 /$ palgrave.fr. 9400234

4 feminist review 812005

(4) (C) 2005 Feminist Review. 0141-7789/05 \$30 www.feminist-review.com 